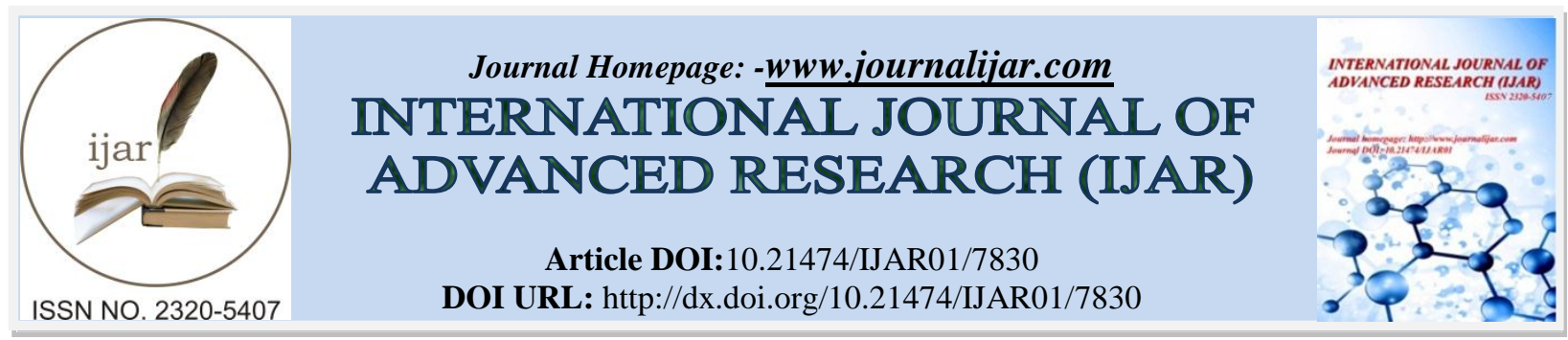

RESEARCH ARTICLE

\title{
THE MODERATION EFFECT OF WHISTLEBLOWING ON ETHICS, COMMITMENT, INDEPENDENCE AND AUDIT QUALITY.
}

Syamsuddin, Yulianus and Syahrir.

Lecturer at the Faculty of Economics and Business Hasanuddin University, Makassar, Indonesia.

\section{Manuscript Info}

\section{Manuscript History}

Received: 7 August 2018

Final Accepted: 9 September 2018

Published: October 2018

Keywords:-

Whistleblowing, ethics, commitment, independence, audit quality.

\begin{abstract}
The purpose of this study was to analyze and examine the moderation effect of whistleblowing on ethics, commitment, independence, and audit quality. The population in this study were all Inspectorate Auditors of South Sulawesi Province. This research was a quantitative study that uses questionnaires, survey methods and Structural Equation Modeling (SEM) PLS analysis equipment. The results obtained show ethics, commitment, independence were influence on audit quality. While Whistleblowing does not directly affect audit quality. Whistleblowing moderates the influence of ethical, commitment, independence variables on audit quality which is pure moderation and strengthens. This research retest the results of research from Aranya and Amernic (1981), Carcello et al (1992), Behn et al (1997), Copley (1998), Brown and Raghunandan (1995), Beasley et al (2001), Chiu (2003), Suraida (2005), Lowensohn et al (2007), Novianti (2007), Varelius (2009). Based on that, researcher use model combination and the results of this study could add or complement existing theories in improving the quality of auditing implementation.
\end{abstract}

Copy Right, IJAR, 2018,. All rights reserved.

\section{Introduction:-}

Whistleblowing is the action of a worker who decides to report to the media, internal or external power about illegal and unethical matters that occur in the work environment. Whistleblowing arises because the Sarbanes-Oxley Act (SOx) encourages employees to report violations that occur without fear of retaliation. The law that emerged due to major scandals that occurred in the US, such as the Enron and WorldCom scandals.

According to Nadler and Schulman (2011) there are four ways of whistleblowing in government accountability, namely, (1) reporting errors or violations of law for authorities, (2) refusing to participate in workplace mistakes, (3) testifying in legal proceedings and (4) leak evidence of errors to the media. According to Rothschild and Miethe (1999) that whistleblower behavior develops for several reasons. First, movements in the economy that are related to improving the quality of education, expertise, and social exclusion of workers. Second, the current economic situation has provided intensive information and has become a driver of information. Third, access to information and ease of publication leads whistleblowing as a phenomenon that cannot be prevented from shifting this economy.

According to Vardi and Wiener (1996), whistleblowing can be seen as an act that is commendable by members of society in general, but in the context of a particular organization cannot accept the action Whistleblowing will arise 
when there is a conflict between employee loyalty and protection of public interests (Varelius , 2009).

Audit quality is the probability that an auditor finds and reports about a violation in his client's accounting system (De Angelo 1981). In the public sector, the Government Accountability Office (GAO, 1986) defines audit quality as: "compliance with professional standards and contractual terms for the audit under consideration". Audit quality is compliance with professional standards and contractual ties during the audit. Mills (1989) in his book "A Management Evaluation Tool" describes the meaning of audit quality, namely "The Audit Quality is a management tool used to evaluate, confirm, or verify activities related to quality".

Research on audit quality is carried out by Carcello et al. (1992) which provides information about the attributes of audit quality by including people who prepare financial statements and users of financial statements as part of the attributes of audit quality, while Behn et al. (1997) conducted the same study by looking at whether quality attributes had a direct influence on client satisfaction, Behn et al (1997) only found 6 attributes of the 12 attributes studied by Carcello et al. (1992) which has a positive influence on client satisfaction.

Some results of whistleblowing research such as Chiu (2003) found a positive relationship between ethical judgments of whistleblowing and the intention to conduct whistleblowing, Varelius (2009) which showed that there was no significant relationship between whistleblowing as a moral problem and employee loyalty and desire to protect public interests. Professional commitment has an influence on whistleblowing (Yuyun 2007). Jeffrey and Weatherholt (1996) examine the relationship between professional commitment, ethical understanding and obedience to rules. The results show that accountants with strong professional commitment make their behavior more directed towards adherence to the rules compared to accountants with low professional commitment.

Whistleblower is a disclosure made by members of an organization on illegal practices or without legal legitimacy under the control of leaders to individuals or organizations that can cause effects of repairing actions (Miceli, 1992). This study re-examined the results of research from Aranya and Amernic (1981), Carcello et al (1992), Behn et al (1997), Copley (1998) Brown and Raghunandan (1995), Beasley et al (2001), Chiu (2003), Suraida ( 2005), Lowensohn et al (2007), Novianti (2007), Varelius (2009).

The purpose of this study was to analyze and examine the effect of whistleblowing moderation on ethics, commitment, independence, and audit quality. Therefore, the results of the research are expected to be the development of future knowledge, especially with regard to audit quality, Whistleblowing, Ethics, commitment and independence. The results of this study are also expected to inspire government auditors so that in carrying out audit duties in addition to meeting professional standards and codes of ethics, they must always have and practice their professionalism in uncovering findings (whistleblowers) in order to produce a quality audit.

This research is expected to add or complete existing theoretical repertoire in improving the quality of auditing implementation. Can be used as a source of information and references to conduct research with topics related to this research, both complementary and continuing.

\section{Literature Review and Concepts Auditing of public sector}

Boynton et al (2006) define auditing as a systematic process for obtaining and evaluating evidence objectively with respect to assertions regarding economic activities and events, to determine the level of suitability between the various assertions and the established criteria. And convey the results to interested parties.

The scope of government audits in the Standard for Audit of Government Operations, Programs, Activities, and Functions (Vanasco, 1995) includes: (1) Financial and Compliance Audits, (2) Economy and efficiency audits, and (3) Programe results andits. The type of public sector audit (government) in accordance with the development and demands of their needs, can be classified into the Financial Audit, Performance Audit and Investigation Audit (Indra Bastian, 2006). The scope of public sector (government) audit work is wider than the private sector (Vanasco 1995) states:

"the responsibilities of auditors of entities in the public sector as regards the law and regulations are similar to those of auditors of limited companies and other entities in the private sector ... However, in some way the responsibilities of auditors of entities in the public sector go beyond those in the private sector by virtue of statutory or other prescribed duties and obligation." 
According to the State Financial Examination Standard (BPK-RI, 2007), the duties of the government auditor include the Financial Audit and Performance Audit, in addition to conducting an Investigative Audit. As stipulated in article 4 paragraph (1) of the Republic of Indonesia Law No. 15 of 2004 concerning the Examination of the Management and Responsibility of State Finance, that the examination of state finances includes financial examinations, performance checks, and audits with certain objectives. The audit for the government sector carried out by the BPK includes an examination of financial management and an examination of the State's financial responsibilities consisting of financial audits, performance audits and audits for specific purposes / investigative audits.

\section{Audit Quality}

The Indonesian Institute of Accountants states that audits conducted by auditors are said to be of high quality, if they meet auditing standards and quality control standards. Furthermore De Angelo (1981) defines audit quality as the probability of an auditor finding and reporting about a violation in his client's accounting system. Deis and Giroux (1992) explain that the ability to find material misstatements in a company's financial statements depends on the auditor's competence while the willingness to report the findings of the misstatement depends on its independence. Auditor quality according to the Regulation of the Minister of State for Administrative Reform No. Per /05/ M.Pan/03/2008 dated March 31, 2008 were auditors who carry out tupoksi effectively, by preparing audit work papers, implementing planning, coordinating and evaluating the effectiveness of audit follow-up, as well as consistency of audit reports.

Audit quality standards consist of: strategic quality, technical quality, and process quality. Strategic quality means the results of the examination must provide information to users of the report in a timely manner. Technical quality is related to the presentation of findings, conclusions, and opinions or suggestions for inspection, namely the presentation must be clear, consistent, accessible, and objective. While the quality of the process refers to the process of audit activities from planning, implementation, reporting, to follow-up of the examination. Audit quality is measured from indicators of strategic quality, technical quality, and quality of processes taken from audit management guidelines (BPK, 2002).

The audit quality attribute developed by Carcello et al (1992) includes 1) the experience of the audit team and KAP in examining the client's financial statements; 2) Expertise / understanding of the client industry; 3) Responsiveness to client needs; 4) Competence of audit team members on accounting principles and audit norms; 5) The attitude of independence in all matters from the individual audit team and KAP; 6) Members 6) the audit team as a group that is careful; 7) KAP has a strong commitment to quality; 8) Involvement of KAP leaders in conducting audits; 9) Implementation of field audits; 10) The involvement of the audit committee before, during and after the audit; 11) High ethical standards of members of the audit team members; 12) Maintain skepticism from members of the audit team.

\section{Whistleblowing (Whistleblower)}

Whistleblowing is the action of a worker who decides to report to the media, internal or external power about illegal and unethical matters that occur in the work environment. A Whistleblower is an employee (employee) or an employee in an organization that reports, witnesses, is aware of a crime or practices that deviate and threaten the public interest in the organization and who decide to disclose the deviation to the public or authorized agency (Wikipedia, Columbia electronic encyclopedia: 2005). For organizations that run their business activities ethically, Whistleblowing is part of the control system, but for organizations that do not carry out their business activities unethically, Whistleblowing can be a threat.

De George (1986) establishes three criteria for fair whistleblowing. First, an organization that can cause harm to its workers or to the broad public interest. Second, errors must be reported first to internal parties who have higher powers, and thirdly, if irregularities have been reported to internal authorities but have no results, and even irregularities continue, reporting of irregularities to external parties can be referred to as citizenship actions. The good one. Whistleblowers are useful as a tool to detect various problems that exist within the organization, such as discrimination, harassment, or other behavioral irregularities that are not in accordance with ethical standards that apply in the organization. So, if implemented seriously, this whistleblower mechanism can also function as a means of control and supervision, which can help improve ethical behavior in the organization, which can also encourage changes in organizational culture in a better direction. The information giver can come from management, 
employees of an organization, or other parties who have interactions with organizational devices.

\section{Ethics}

According to Cohen et al. (2001), each individual's actions are first determined by his needs. These needs, after interacting with personal experiences and the individual value system, will determine expectations or goals in each behavior, before finally the individual determines what action will be taken.

Related to the issue of ethics, the Big Indonesian Dictionary, Ministry of Education and Culture, (1988), defines ethics as (1) a collection of principles or values relating to morals; (2) the value of right and wrong adopted by a group or society, while ethics is the knowledge of what is good and what is bad and about rights and moral obligations (morals). According to Ibrahim Abdulah Assegaf (2001) ethics is a personal discipline in relation to the environment that is more than what is only determined by the Act. So, the code of ethics in principle is a system of moral principles that are applied in a professional group that is set together. The code of ethics of a profession is a provision of behavior that must be obeyed by all those who carry out the duties of the profession, such as doctors, lawyers, police, accountants, appraisers, and other professions.

\section{Commitment}

Understanding organizational commitment according to Riggio (2000) "Organizational commitment is a workers' feelings and attitudes about the entire work organization" means organizational commitment is all the feelings and attitudes of employees towards everything related to the organization they work in, including their work. Buttery, Hurford, and Simpson (Audit in the Public Sector, 1993) mention some other personal qualities that an auditor must possess, such as intelligence, good behavior, high commitment, and good imagination ability to create creative attitudes and full of innovation. Luthans (1995) defines organizational commitment as:

1. A strong desire to remain a member of particular organization

2. A willingness to exert high levels of effort on behalf of the organization

3. A definite belief in, and acceptance of, the values and goals of the organization

Siders et al. (2001), and Fernando et al (2005) from the results of their research, also gave the same conclusion that organizational commitment has a positive influence on performance. Such results, further can be explained that the right commitment will provide high motivation and have a positive impact on the performance of someone on the job Jeffrey and Weatherholt (1996) examined the relationship between professional commitment, ethical understanding and obedience to the rules. The results show that accountants with strong professional commitment make their behavior more directed towards adherence to the rules compared to accountants with low professional commitment.

\section{Independence}

Independence means a mental attitude that is free from influence, not controlled by other parties, not dependent on others. Independence also means that there is honesty in the auditor in considering the facts and the existence of objective considerations that are not impartial in the auditor in formulating and expressing their opinions. Arens et al (2003) define independence: "A member in public practice shall be independence in the performance a professional service as require by standards promulgated by bodies designated by a council". Mulyadi (2002) defines as follows: "Circumstances free from influence, not controlled by other parties, does not depend on other organizations. An independent public accountant must be a public accountant who is not affected and influenced by various forces that come from outside the self-accountant in considering the facts he encounters in the examination.

American Institute of Certified Public Accountant (AICPA) about independence said that: "Members in public practice must be independent in carrying out their professional services as required by standards compiled by institutions formed by the board." Indonesian Code of Ethics for Accountants CHAPTER IV Article 13 paragraph 1 states that: "Every member the profession must maintain an independent attitude. He must be free from all interests that can be viewed as incompatible with his integrity and objectivity. Regardless of the truth effects of that interest. "The Public Accountant Professional Standard specifically regulates public independence in the second general standard (SA.220) which reads:

"In all matters relating to the assignment, independence in a mental attitude must be maintained by the auditor. In SPAP (IAI, 2001: 220.1) auditors are required to be independent, meaning that they are not easily influenced, 
because they carry out their work for the public interest (distinguished in terms of their practice as internal auditors). There are three aspects of the independence of an auditor, namely as follows:

1. Independence in fact. Auditors must have high honesty, a close relationship with objectivity.

2. Independence in appearance. The other party's view of the auditor regarding the implementation of the audit.

3. Independence in competence. Independence from the point of view of expertise is closely related to professional auditor skills.

\section{Agency Theory}

Jensen \& Meckling (1976) defines that agency relations as a contract in which one is more (principally) hires another person (agent) to do some services for their benefit by delegating some authority to the decision making agent. Conflicts of interest will arise from the delegation of tasks given to agents, namely agents not in the interests of maximizing the welfare of the owner, but having a tendency to pursue their own interests at the expense of the interests of the owner. The auditor is one of the parties related to the agency relationship (between the agent and the principal).

According to contracting theory (Watt \& Zimmerman, 1986) which is also known as the principal and agent theory (the principle agent theory) states that the relationship between parties in a company; managers, shareholders, creditors, government and society will be difficult to create because of conflicting interests. Conflict between management and owner occurs because the owner on one side wants the management to have the opportunity to satisfy their interests without being directly observed by the owner. Relations between parties that have these interests have been realized optimally through the creation of several mechanisms that are able to reduce management's actions to harm the owner and encourage the owner to entrust management to management. According to this theory, the mechanism can be realized in accounting and auditing. Both accounting and auditing have a strategic market value in helping to create optimal and economical relationships with the costs obtained and accounted for in terms of market value.

\section{Stewardship Theory}

This theory is based on human behavior (behavior), human patterns (model of a man), and psychological mechanisms (motivation, identification and power) in an organization that practices leadership as an aspect that plays an important role for achieving goals. This theory is rooted in psychology and sociology which leads to an attitude of service (Donaldson, 1990). This theory is how to create organizational structures that can help managers to make decisions and choices to optimize organizational performance.

Donaldson (1990) suggested the core of Stewardship theory that auditors are agents of principals who act in accordance with the interests of the people (principals). In this theory, it is analogous that the leaders (executives) are not motivated for individual goals but rather are aimed at the interests of the organization and act according to the wishes of the principal (the people). Referring to this theory, steward behavior is collective, because stewards are guided by behavior and organizational goals can be achieved, stewardship theory assumes that there is a very strong relationship between organizational success and principal satisfaction.

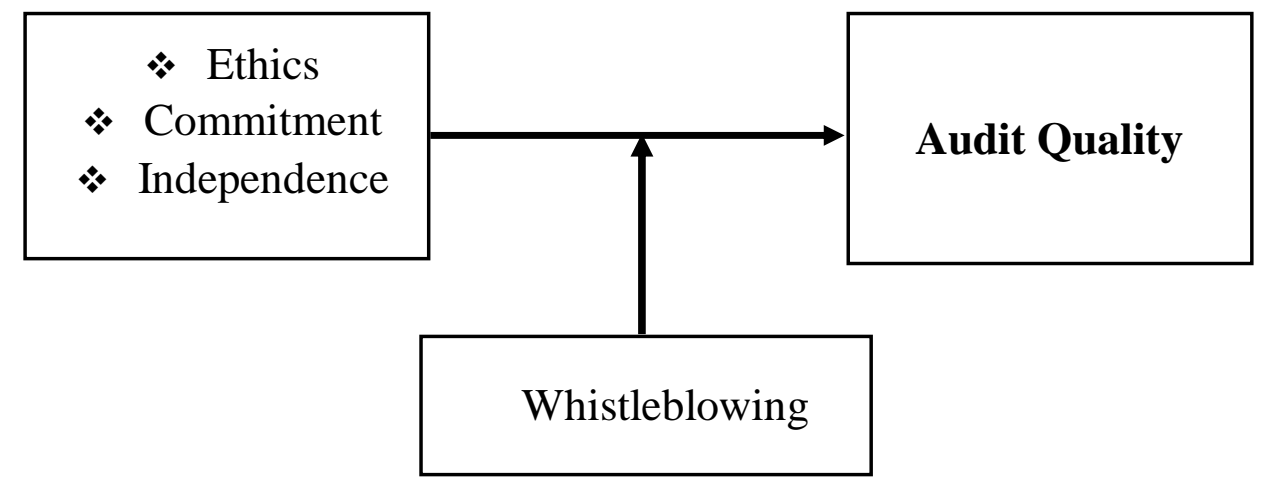

Figure of Conceptual Framework for Research 


\section{Hypotheses}

Based on the thought framework that has been proposed, the following hypothesis is formulated: Ethics in the profession is strongly influenced by the cultural environment or society where the profession is located, the profession environment, organization or place of work and personal experience (Hunt and Vitell 1989). Likewise the effectiveness of Whistleblowing the need for understanding ethics and a climate of openness (KNKG 2008). Ethics relates to the question of how people will behave towards each other, according to the Big Dictionary of Indonesian Language (1995) ethics means the value of right and wrong adopted by a group or society. Based on the description above the writer formulates a hypothesis.

H1: Ethics, Commitment, Independence are effect on Whistleblowing

Aranya and Amernic (1981) say organizational commitment is positively related to professional commitment. While the results of the research Ketchand and Strawser (1998) also have tested various dimensions of organizational commitment and found that there is a relationship between organizational commitment and performance. The study of Siders et al (2001), and Fernando et al (2005) from the results of his research, also gives the same conclusion that organizational commitment has a positive influence on performance. Jeffrey and Weatherholt (1996) examine the relationship between professional commitment, ethical understanding and obedience to rules. Based on the description above the writer formulates a hypothesis.

H2: Commitment effects on Whistleblowing

Supriyono (1988) has conducted research on auditor independence in Indonesia. This study examines the factors that influence auditor independence, namely (1) ties of financial decisions and business relationships with clients; (2) competition between KAP; (3) providing services other than audit services; (4) length of audit assignment; (5) large accounting firm; and (6) the amount of the audit fee. Respondents selected included financial directors of companies that had gone public, KAP partners, bank credit officers and non-bank financial institutions, and Bapepam. The results of the study by Pany and Reckers (1980) show that even though the amount of the prize has a significant effect on auditor independence, the size of the client does not significantly influence other studies regarding the independence of De Angelo (1981). Hussey and Lan (2001), Deis and Giroux (1992) Shockley (1981), Knapp (1985). Based on the description above the writer formulates a hypothesis.

H3: Independence effects on Whistleblowing

Research conducted by Varelius (2009) which shows that there is no significant relationship between whistleblowing as a moral problem with employee loyalty and the desire to protect the public interest. Keenan and Krueger (1992) also surveyed 6500 executives and managers randomly showed different results, i.e. only fifty percent of managers found violations but considered the fraud was reasonable and did not report it. Chiu's (2003) study found a positive relationship between ethical judgment on whistleblowing and the intention to conduct whistleblowing. Finn and Lampe (1992) attempt to model a whistleblowing auditor's decision. The results of this study indicate that the auditor's ethical decisions and whistleblowing decisions relate significantly. The majority of auditors agree that certain actions are unethical, they are very reluctant to submit complaints to others who do not have the same beliefs. Other research James (1984). Brown et al (1995). Near et al (1996), Arnold et al (1991), Finn et al (1992), and Mustafa et al (2012), as for the hypothesis presented as follows.

H4: Whistleblowing affects Audit Quality.

Ethics in the profession is strongly influenced by the cultural environment or society where the profession is located, the profession environment, organization or place of work and personal experience (Hunt and Vitell 1989). Likewise, the effectiveness of Whistleblowing is the need for understanding ethics and transparency of openness (KNKG 2008). Based on the description above the writer formulates a hypothesis.

H5: Whistleblowing moderates the effect of Ethics on audit quality.

According to Riggio (2000) "Organizational commitment is a workers' feelings and attitudes about the entire work organization" means that organizational commitment is all the feelings and attitudes of employees towards everything related to the organization they work in, including their work. Buttery, Hurford, and Simpson (Audit in the Public Sector, 1993) mention some other personal qualities that an auditor must possess, such as intelligence, good behavior, high commitment, and good imagination ability to create creative attitudes and full of innovation. Based on the description above the writer formulates a hypothesis.

H6: Whistleblowing moderates the effect of commitment to audit quality. 
Definition of independence in The CPA Handbook according to E.B. Wilcox is an important auditing standard because independent accountant opinion aims to add credibility to the financial statements presented by management. If the accountant is not independent of his client, then his opinion will not give any additional (Mautz and Sharaf, 1993: 246).

H7: Whistleblowing moderates the effect of independence on audit quality.

\section{Research Method}

This research was carried out for 6-7 months in 2017. The study was conducted at the Inspectorate Auditor of South Sulawesi Province. This study includes survey research methods, namely the method of collecting primary data using instruments, namely questionnaires that range in scope such as social environment, activities, opinions and attitudes (Bungin, 2011: 2). This research includes explanatory research, which is a research that attempts to explain the relationship between variables through hypothesis testing (Singarimbun and Effendi, 1995: 5).

Based on the data analysis, this research is a quantitative research, because it analyzes sample data with inductive statistics and generalized descriptive statistics for the population conclusion (Indriartono and Supomo, 2002: 15). Data collected is cross sectional data, obtained from respondents in responding to indicators related to ethical variables, commitment, independence, whistleblower and audit quality.

In this study, tested the effect of whistleblowing moderation on ethics, commitment, independence, and audit quality, so that this study involved 5 variables, namely ethical variables, commitment, independence, whistleblower and audit quality.

Based on how to determine the values in the model, it can be grouped into exogenous variables (exogenous variables) and endogenous variables (endogenous variables). The usual exogenous variable is denoted by $\mathrm{X}$, while the endogenous variable is denoted by Y.

To obtain data as a result of observations on each research variable, a research instrument in the form of a questionnaire was used. In this study to measure variables used a Likert scale of 5 (five) categories, namely strongly Disagree (STS / score 1), Disagree (TS / score 2), Doubtful / Neutral (RR / score 3), Agree (S / score 4), and Strongly Agree (SS / score 5) in the form of questions on each item of research instrument question (Sekaran, 2006: 25).

This study involved an instrument in the form of a questionnaire, so that it required testing the validity and reliability of the instrument. Validity test is carried out to ensure that each item in the research instrument is able to measure the research variables specified. The validity of an instrument item can be known by comparing the Pearson product moment correlation index with a significance level of $5 \%$ with its critical value, where $\mathrm{r}$ can be used by the formula (Bungin, 2009: 35-36). If the correlation value> 0.3, then it is declared valid and otherwise declared invalid (Indriantoro and Supomo, 2002: 48).

Reliability is an index that shows the extent to which a measuring device can be trusted or reliable. To test used Alpha Cronbach. The instrument can be said to be reliable if it has a reliability reliability coefficient of 0.6 or more (Bungin, 2009:35-36).

To measure the variables, the questionnaire was distributed to respondents. For each answer a score is given and the score obtained has an ordinal measurement level. The score or weight value used is strongly agree (5) to strongly disagree (1). The analytical tools used in this study were Structural Equation Modeling (SEM) with PLS auxiliary programs. Structural Equation Modeling (SEM) is a set of statistical techniques that allows testing a series of relationships between variables simultaneously. The assumptions that must be met in this process are generally as follows: (1) The minimum sample size is 100 samples, (2) Meet the assumptions of normality and linearity, (3) There are no outliers, (4) There is no multicollinearity, and (5) Fit model is met.

\section{Results:-}

\section{Respondent Data}

The population in this study were all auditors and staff at the Inspectorate of South Sulawesi Province as many as 149 people. The questionnaire was distributed to 149 people but only 117 people filled out, because there were some who were temporarily outside the area. 


\section{Test Validity and Reliability of Instruments}

This study uses an instrument in the form of a questionnaire (presented in Appendix 1) using a 5-Likert Scale choice of answers from strongly disagree to strongly agree. Before the data from the questionnaire collection can be used for further analysis, it is necessary to test the validity and reliability of the instrument. Validity testing with Pearson correlation, the instrument is declared valid if the correlation value $>0.3$.

\section{Description of Research Variables}

This study involved five variables, namely Ethics (X1), Commitment (X2), Independence (X3), Whistleblower (M), and Audit Quality (Y). The five variables measured using a 5-level Likert scale. The following section presents a description of each research variable in order to find out the description of the conditions of the variables studied based on the measurement of the frequency distribution of respondents' answers, as well as the mean (mean) with the criteria presented.

In the first part is presented a description of the Ethics variable (X1). This variable is measured by three indicators, namely concern for professional ethics (X1.1), ethical awareness (X1.2), and locus of control (X1.3). Each indicator is measured by 2 items. Frequency distribution of response responses for each question item on each indicator and variable in full is presented in Appendix 3.

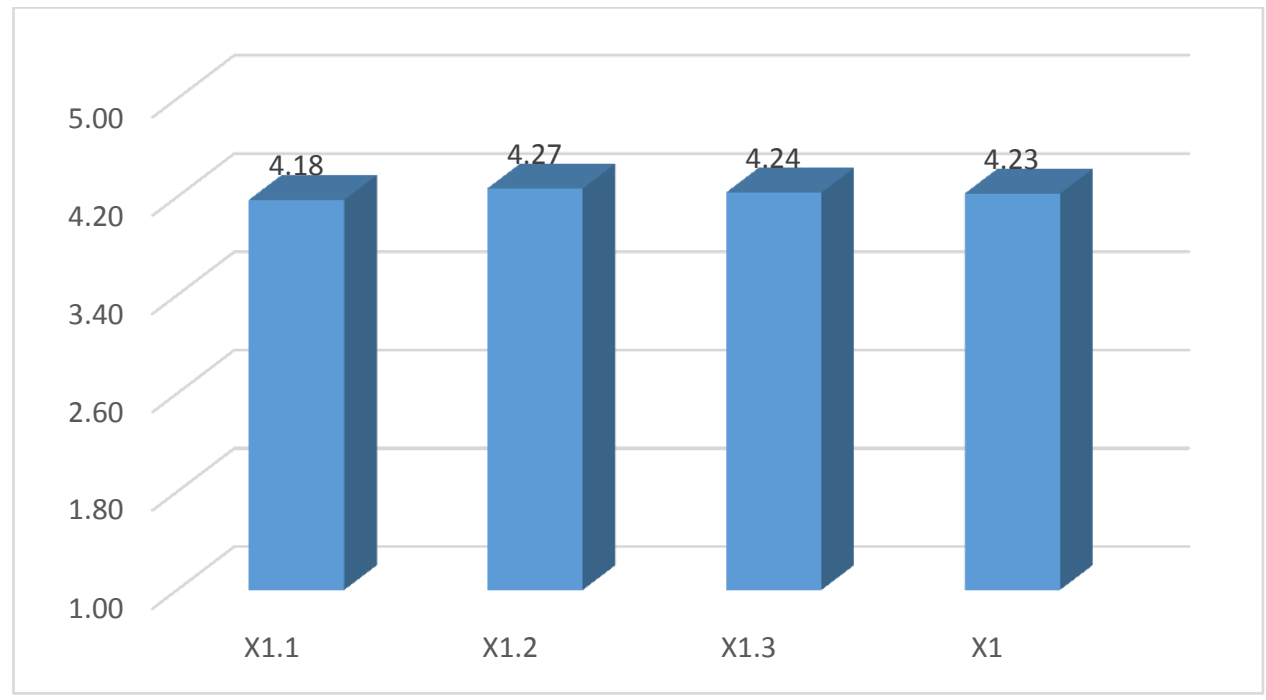

Figure:-Description of Average Indicators on Ethical Variables (X1)

Source: Primary Data Processed, 2017 (Attachment 3)

The figure above shows that the mean (mean), one of the three indicators is in the high category (average between 3.41-4.20), and the other two indicators are in the very high category (average between 4.21-5.00), where the second indicator is ethical awareness (X1.2) has the highest mean (mean) of 4.27 and in the first indicator that concern for professional ethics (X1.1) has the lowest mean (mean) of 4.18. Overall, respondents perceive the Ethics variable (X1) with an average of 4.23 (very high category). This indicates that Ethics (X1) owned by respondents is in the very high category (average between 4.21-5.00).

In the second part, a description of the Commitment variable (X2) is presented. This variable is measured by three indicators, namely affective commitment (X2.1), continuance commitment (X2.2), and normative commitment (X2.3). Each indicator is measured by 2 items. Frequency distribution of response responses for each question item on each indicator and variable in full is presented in Appendix 3, and summarized in the following Figure. 


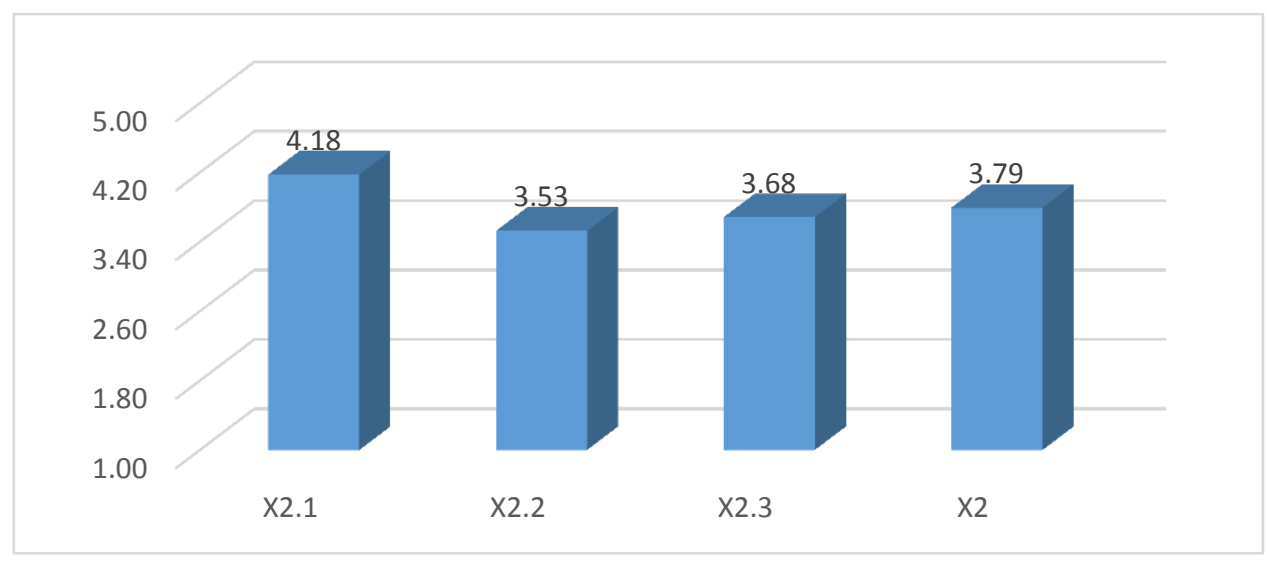

Figure:-Description Average Indicator on Commitment Variables (X2) Source: Primary Data Processed, 2017 (Attachment 3)

The figure above shows that from the mean (mean) the three indicators are in the high category (average between 3.41-4.20), where the first indicator is affective commitment (X2.1) has the highest mean (mean) of 4.18 and the second indicator, continuance commitment (X2.2), has the lowest mean value of 3.53. Overall, respondents perceive the Commitment variable (X2) with an average of 3.79 (very high category). This indicates that the Commitment (X2) owned by the respondents is in the high category (average between 3.41-4.20).

In the third part, a description of the independence variable (X3) is presented. This variable is measured by three indicators, namely personal auditor (X3.1), relationship with professional peer (X3.2), and relationship with audit (X3.3). Each indicator is measured by 2 items. Frequency distribution of response responses for each question item on each indicator and variable in full is presented in Appendix 3, and summarized in the following Figure.

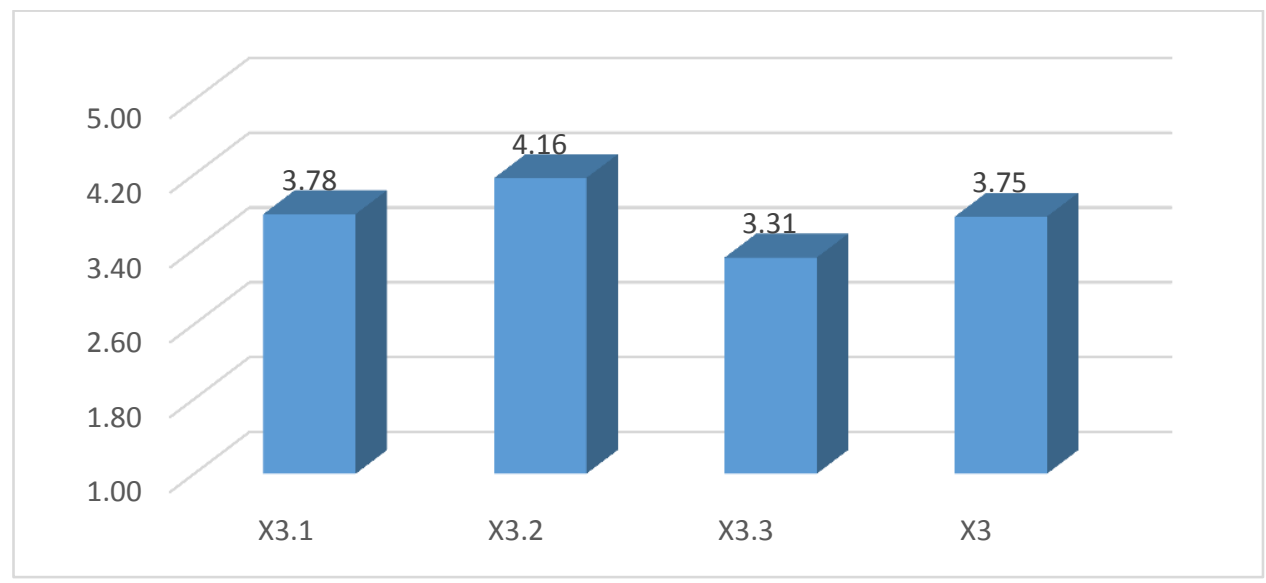

Figure:-Description of Average Indicators on Independence Variables (X3) Source: Primary Data Processed, 2017 (Attachment 3)

The figure above shows that the mean (mean) of the three indicators are in the high category (average between 3.414.20), the second indicator is the relationship with professional colleagues (X3.2), has the highest mean (mean) amounting to 4.16 and the third indicator, namely the relationship with the audit (X3.3) has the lowest mean (mean) of 3.31. Overall, respondents perceive the Independence variable (X3) with an average of 3.75 (high category). This indicates that the Independence (X3) owned by respondents is in the high category (average between 3.41-4.20).

In the fourth part, the Whistleblower (M) variable description is presented. This variable is measured by the four indicators, namely accountability (M1), finding fraud (M2), participation of all parties (X3.3), and the role for the benefit of society (M4). Each indicator is measured by 1 to 2 items. The frequency distribution of response responses for each question item on each indicator and the variable in full is presented in Appendix 3, and summarized in Table 4.6 and Figure 4.4 below: 


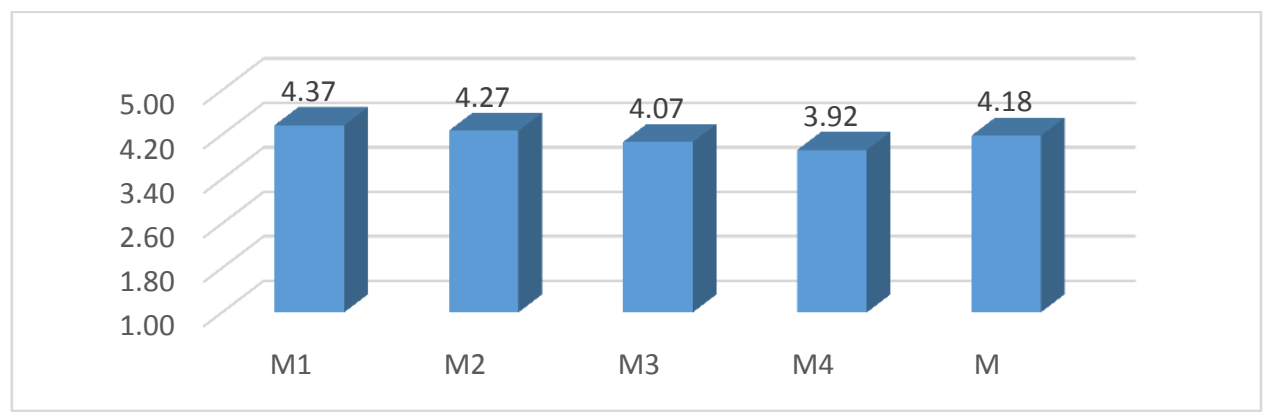

Figure:-Description of Average Indicator on Whistleblower Variables (M) Source: Primary Data Processed, 2017 (Attachment 3)

The figure above shows that the average (mean) values of two of the four indicators are in the high category (average between 3.41-4.20), and the other two indicators are in the very high category (average between 4.21-5.00) with indicators first, accountability (M1) has the highest mean (mean) of 4.37 and in the fourth indicator, the role for the public interest (M4) has the lowest mean (mean) of 3.92. Overall, respondents perceive the Whistleblower (M) variable with an average of 4.18 (high category). This indicates that Whistleblower (M) owned by respondents is in the high category (average between 3.41-4.20).

The fifth section presents a description of the Audit Quality variable (Y). This variable is measured by three indicators, namely field work guidelines (Y1), leadership involvement (Y2), and audit work team (Y3). Each indicator is measured by 1 to 2 items. Frequency distribution of response responses for each question item on each indicator and variable in full is presented in Appendix 4, and summarized in the following Figure:

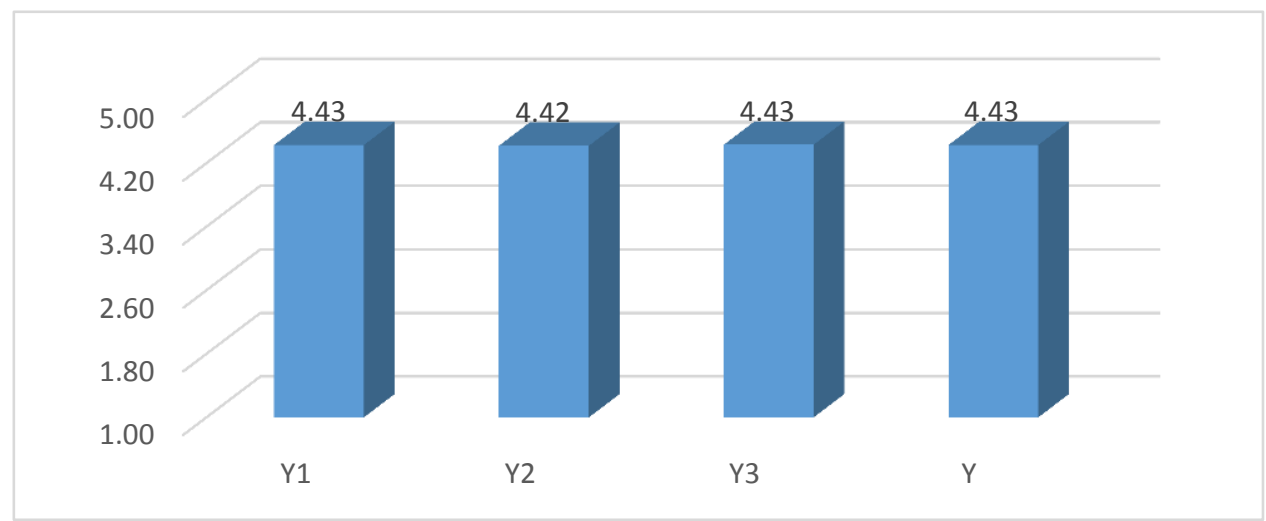

Figure:-Description of Average Indicators on Audit Quality Variables (Y) Source: Primary Data Processed, 2017 (Attachment 3)

The figure above shows that the mean (mean) of the three indicators are in the very high category (average between 4.21-5.00), with the first and third indicators namely the field work guidelines (Y1) and the audit work team (Y3) the same- the same has the highest mean (mean) of 4.43 and in the second indicator, the involvement of leaders (Y2) has the lowest mean (mean) of 4.42. Overall, respondents perceive audit quality variables (Y) with an average of 4.43 (very high category). This indicates that audit quality (Y) owned by respondents is in the very high category (average between 4.21-5.00).

\section{Data Analysis Results: PLS}

Testing Linearity Assumptions and $\mathbf{Q}^{2}$ Predictive

There is one assumption in the PLS model that must be met, namely linearity assumptions. The linearity assumption is the assumption that all relationships are linear. Linearity test, to check it can be done by making scatter diagrams or curve fit approaches (in SPSS software). Linearity assumption testing using curve fit method is done with SPSS software. The reference used is the principle of parsimony, namely (1) when the linear model is significant, or (2) when all possible models are non-significant. The model specifications used as the basis for testing are linear, 
quadratic, cubic, inverse, logarithmic, power, S, compound, growth and exponential models. These two provisions indicate that linearity assumptions are met. The following table presents the results of the linearity of the relationship between variables:

Table. Testing Linearity Assumptions

\begin{tabular}{|c|l|c|}
\hline Relationship & \multicolumn{1}{|c|}{ Test Results } & Information \\
\hline $\mathrm{X} 1 \rightarrow \mathrm{Y}$ & $\begin{array}{l}\text { Significant Linear Model } \\
\text { (Sig Linier 0.000< 0.05) }\end{array}$ & Linier \\
\hline $\mathrm{X} 2 \rightarrow \mathrm{Y}$ & $\begin{array}{l}\text { Significant Linear Model } \\
\text { (Sig Linier 0.000< 0.05) }\end{array}$ & Linier \\
\hline $\mathrm{M} \rightarrow \mathrm{Y}$ & $\begin{array}{l}\text { Significant Linear Model } \\
\text { (Sig Linier } 0.000<0.05)\end{array}$ & Linier \\
\hline
\end{tabular}

Source: Primary data processed, 2017 (Attachment 2)

From the table above shows the seven relationships between variables (seven hypotheses), all linear models are significant, because the sig (p-value) linear model is smaller than 0.05 , so the linearity assumption is fulfilled. Thus, the twelve relationships between variables in this study are in linear form, so PLS can be used. Examination of the goodness of fit model in PLS can be seen from the predictive-relevance (Q2) value. Q2 value is calculated based on the R2 value of each endogenous variable. The measurement of audit quality endogenous variables obtained R2 is 0.765 or $76.5 \%$. This indicates that $76.5 \%$ of Audit Quality is influenced by Ethics, Commitment, Independence and Whistleblower (M).

Thus the predictive relevance value $\left(\mathrm{Q}_{2}\right)$ is obtained as follows:

$\mathrm{Q}^{2}=1-\left(1-\mathrm{R}_{1}{ }^{2}\right)\left(1-\mathrm{R}_{2}{ }^{2}\right)$

$\mathrm{Q}^{2}=1-(1-0.765)$

$\mathrm{Q}^{2}=0.765$

The results of the calculation show a predictive-relevance value of 0.765 or $76.5 \%$ of high value, so that the model is worthy of being said to have relevant predictive values. The predictive relevance value of $76.5 \%$ indicates that the diversity of data that can be explained by the PLS model built is $76.5 \%$ or in other words the information contained in the $76.5 \%$ data can be explained by the model. While the remaining $23.5 \%$ is explained by other variables (which are not contained in the model) and errors.

\section{Outer Model}

In PLS Analysis there are two models, namely the outer model and the Inner model. The value of outer loading (for reflexive indicators) and outer weight (for formative indicators) shows the weight of each indicator as a measure of each latent variable. Indicator with the largest outer loading or outer weight indicating that the indicator is the strongest (dominant) variable gauge. The Ethical Variable (X1) consists of three indicators. The following table and image are presented as shown by the outer loading of indicators from the Ethics variable (X1).

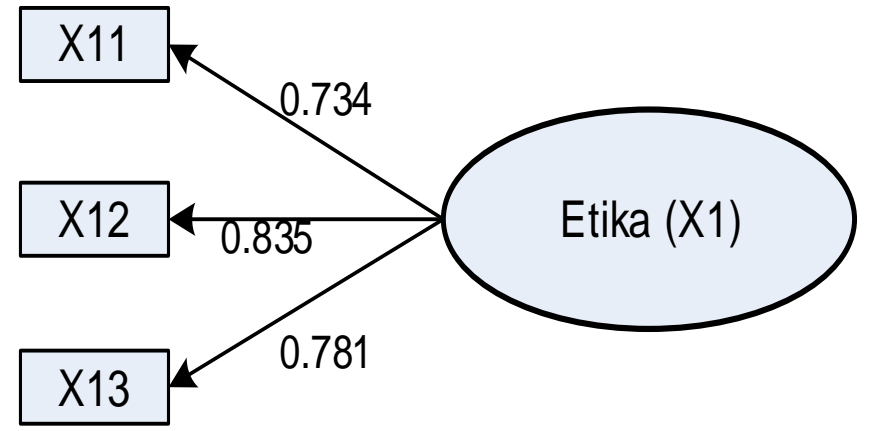

Figure. Measurement of Ethical Variable Models (X1)

The first indicator on the measurement of the Ethics variable (X1) is Concern about professional ethics (X1.1), obtained by outer loading of 0.734 , and p-value of $<0.001(<0.05)$. Thus the indicator of concern for professional ethics (X1.1) is significant as a measure of Ethics (X1). The level of ethics (X1) is determined by the high and low awareness of professional ethics (X1.1). 
The second indicator on the measurement of Ethics (X1) is Ethical Awareness (X1.2), obtained by outer loading of 0.835 , and $\mathrm{P}$-value of $<0.001<0.05$ (significant). Thus the indicator of Ethical Awareness (X1.2) is significant as a measure of Ethics (X1). The high and low Ethics (X1) is determined by the high and low ethical awareness (X1.2).

The third indicator on the measurement of the Ethics variable (X1) is Locus of control (X1.3), the outer loading is 0.781 , and the P-value is $<0.001<0.05$ (significant). Thus the Locus of control indicator (X1.3) is significant as a measure of Ethics (X1). The high and low Ethics (X1) is determined by the high and low Locus of control (X1.3).

The three indicators are Caring for professional ethics (X1.1), Ethical Awareness (X1.2), and Locus of control (X1.3) significant as a measure of Ethics (X1). From the magnitude of the highest outer loading coefficient, it is found that ethical awareness (X1.2) is the strongest measure of ethics (X1). That is, Ethics (X1), mainly seen from the high indications of ethical awareness (X1.2). The strongest measurement to the weakest Ethics variable (X1) is as follows: Ethical awareness (X1.2), Locus of control (X1.3), Concern for professional ethics (X1.1). The second part presents the Commitment variable measurement model (X2). This variable is measured by three indicators, namely affective commitment (X2.1), Continuance commitment (X2.2), and Normative commitment (X2.3).

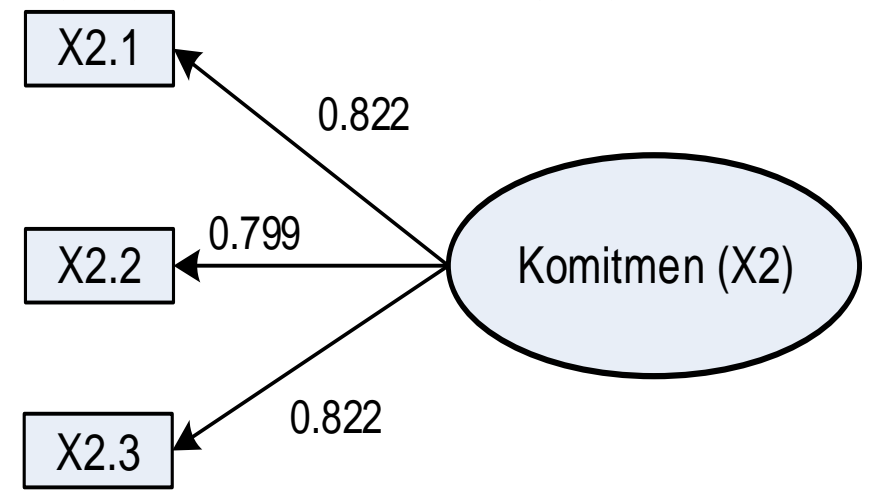

Figure. Variable Commitment Measurement Model (X2)

The first indicator on the Commitment (X2) variable measurement is Affective commitment (X2.1), the outer loading is 0.822 , and the p-value is $<0.001(<0.05)$. Thus the indicator of Affective commitment $(\mathrm{X} 2.1)$ is significant as a measure of Commitment (X2). The high and low Commitment (X2) is determined by the high and low affective commitment (X2.1).

The second indicator on the measurement of the Commitment variable (X2) is Continuance commitment (X2.2), obtained by the outer loading of 0.799 , and the P-value of $<0.001<0.05$ (significant). Thus the indicator Continuance commitment (X2.2) is significant as a measure of Commitment (X2). The high and low Commitment (X2) is determined by the high and low Continuance commitment (X2.2).

The third indicator on the measurement of the Commitment (X2) variable is Normative commitment (X2.3), the outer loading is obtained at 0.822 , and the $\mathrm{P}$-value is $<0.001<0.05$ (significant). Thus the Normative commitment indicator (X2.3) is significant as a measure of Commitment (X2). The level of commitment (X2) is determined by the high and low normative commitment (X2.3).

The three indicators are Affective commitment (X2.1), Continuance commitment (X2.2), and Normative commitment (X2.3), significant as a measure of Commitment (X2). From the highest outer loading coefficient, it is found that Affective commitment (X2.1) and Normative commitment (X2.3) are the strongest measure of Commitment (X2). That is, Commitment (X2), mainly seen from the high indications of Affective commitment (X2.1) and normative commitment (X2.3). The strongest measurement to the weakest Commitment variable (X2) is as follows: Affective commitment (X2.1), normative commitment (X2.3) and Continuance commitment (X2.2).

In the third part, the independence (X3) variable measurement model consists of three indicators. The following is presented the results table and image of the outer loading of the indicators of the Independence variable (X3). 


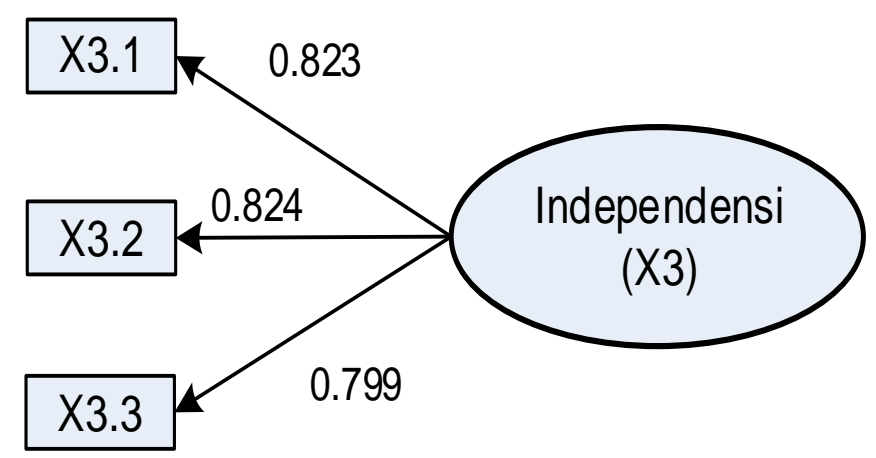

Figure:-Measurement of Independence Variable Model (X3)

The first indicator on the measurement of the Independence variable (X3) is the Personal auditor (X3.1), the outer loading is obtained at 0.823 , and the p-value is $<0.001(<0.05)$. Thus the Personal auditor (X3.1) indicator is significant as an Independence gauge (X3). High and low Independence (X3) is determined by the level of personal auditor (X3.1).

The second indicator on the measurement of the Independence variable (X3) is the relationship with a professional colleague (X3.2), the outer loading is obtained for 0.824 , and the P-value is $<0.001<0.05$ (significant). Thus the indicator of relationship with professional colleagues (X3.2) is significant as a measure of Independence (X3). High and low Independence (X3) is determined by the high and low relationship with professional colleagues (X3.2).

The third indicator on the measurement of the Independence variable (X3) is the relationship with the audit (X3.3), obtained by the outer loading of 0.799 , and the P-value of $<0.001<0.05$ (significant). Thus, the Relationship with audit indicator (X3.3) is significant as an Independence gauge (X3). High and low Independence (X3) is determined by the high and low relationship with the audit (X3.3).

The three indicators are Personal auditor (X3.1), Relations with professional colleagues (X3.2), and Relationships with audits (X3.3) are significant as an Independence gauge (X3). From the highest outer loading coefficient, it is found that the relationship with colleagues is professional (X3.2) as the strongest measure of independence (X3). That is, Independence (X3), mainly seen from the high indication of relationship with a professional colleague (X3.2). The strongest measurement to the weakest Independence variable (X3) is as follows: Relationships with colleagues are professional (X3.2), Personal auditor (X3.1), and Relationships with audits (X3.3).

In the fourth part, a Whistleblower (M) variable measurement model is presented. This variable is measured by four indicators, namely Accountability (M.1), finding fraud (M.2), Participation of all parties (M.3) and Role for the benefit of society (M.4). The following figure presents a Whistleblower (M) variable measurement model.

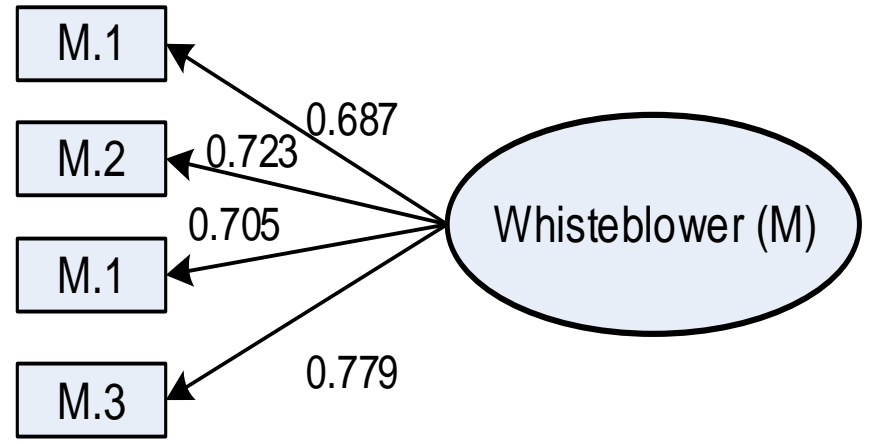

Figure:-Variable Whistleblower Measurement Model (M)

The first indicator on the variable Whistleblower (M) is Accountability (M.1), the outer loading is 0.687 , and the pvalue is $<0.001(<0.05)$. Thus the Accountability indicator (M.1) is significant as a Whistleblower $(\mathbf{M})$ gauge. The low level of the Whistleblower (M) is determined by the high and low Accountability (M.1).

The second indicator on measuring the Whistleblower $(\mathrm{M})$ variable is finding cheating (M.2), the outer loading is 0.723, and the P-value is $<0.001<0.05$ (significant). Thus the indicator finds cheating (M.2) is significant as a 
Whistleblower (M) gauge. The low height of the Whistleblower (M) is determined by the low height of finding cheating (M.2).

The third indicator on Whistleblower $(\mathrm{M})$ variable measurement is the participation of all parties (M.3), the outer loading is 0.705 , and the P-value is $<0.001<0.05$ (significant). Thus the indicator of Participation of all parties (M.3) is significant as a Whistleblower (M) gauge. The low or low Whistleblower (M) is determined by the high and low participation of all parties (M.3).

The fourth indicator on the measurement of Whistleblower (M) variable is the role for the benefit of society (M.4), the outer loading is 0.779 , and the P-value is $<0.001<0.05$ (significant). Thus the indicator of the role for the benefit of society (M.4) is significant as a Whistleblower (M) gauge. The height of the Whistleblower (M) is determined by the high and low Role for the benefit of the community (M.4).

The four indicators are Accountability (M.1), finding fraud (M.2), Participation of all parties (M.3), Role for the benefit of society (M.4) is significant as a Whistleblower (M) measure. From the magnitude of the highest outer loading coefficient, it is found that the role is for the benefit of the community (M.4) as the strongest measuring Whistleblower (M). This means that Whistleblower (M) is mainly seen from the high indication of Role for the benefit of the community (M.4). The strongest measurement to the weakest Whistleblower variable (M) is as follows: Role for the benefit of the community (M.4), Finding fraud (M.2), Participation of all parties (M.3), and Accountability (M.1).

In the fifth section presented the Audit Quality variable measurement model (Y). This variable is measured by three indicators, namely field work guidelines (Y1.1), leadership involvement (Y1.2), and audit work team (Y1.3). The following figure presents the Audit Quality variable measurement model (Y).

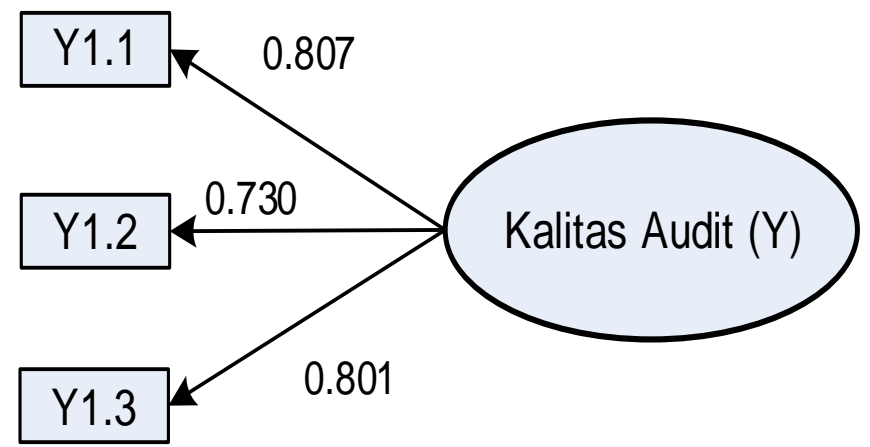

Figure:-Audit Quality Variable Measurement Model (Y)

The first indicator on the measurement of the Audit Quality variable (Y) is the field work guide (Y1.1), the outer loading is 0.807 , and the p-value is $<0.001(<0.05)$. Thus the indicator of field work guidelines $(\mathrm{Y} 1.1)$ is significant as a measure of Audit Quality (Y). High and low audit quality (Y) is determined by the high and low field work guidelines (Y1.1).

The second indicator on the measurement of Audit Quality (Y) is Leadership Involvement (Y1.2), the outer loading is 0.730 , and the $\mathrm{P}$-value is $<0.001<0.05$ (significant). Thus the indicator of leadership involvement (Y1.2) is significant as a measure of audit quality (Y). The high and low quality of audit (Y) is determined by the high and low involvement of leaders (Y1.2).

The third indicator on the measurement of Audit Quality (Y) is the audit work team (Y1.3), the outer loading is 0.801 , and the P-value is $<0.001<0.05$ (significant). Thus, the audit work team indicator (Y1.3) is significant as a measure of Audit Quality (Y). The high and low quality of audit (Y) is determined by the high and low audit work team (Y1.3).

The three indicators are field work guidelines (Y1.1), leadership involvement (Y1.2), and the audit work team (Y1.3) are significant as a measure of audit quality (Y). From the magnitude of the outer loading coefficient the highest is found that the Fieldwork Guidelines (Y1.1) as the strongest measure of Audit Quality (Y). That is, Audit 
Quality (Y), mainly seen from the high indication of field work guidelines (Y1.1). The strongest measurement to the weakest field work guideline variable (Y1.1), audit work team (Y1.3) and leadership involvement (Y1.2).

\section{Inner Model}

In the second part PLS analysis is a structural model or structural model interpretation. Structural model presents the relationship between research variables the structural coefficient of the model states the magnitude of the relationship between one variable and another. There is a significant influence between variables one on other variables, if the P-value is $<0.05$. In PLS there are two influences which are direct effect and indirect effect. The complete analysis results are presented in Appendix 4, and summarized in Figure for direct influence.

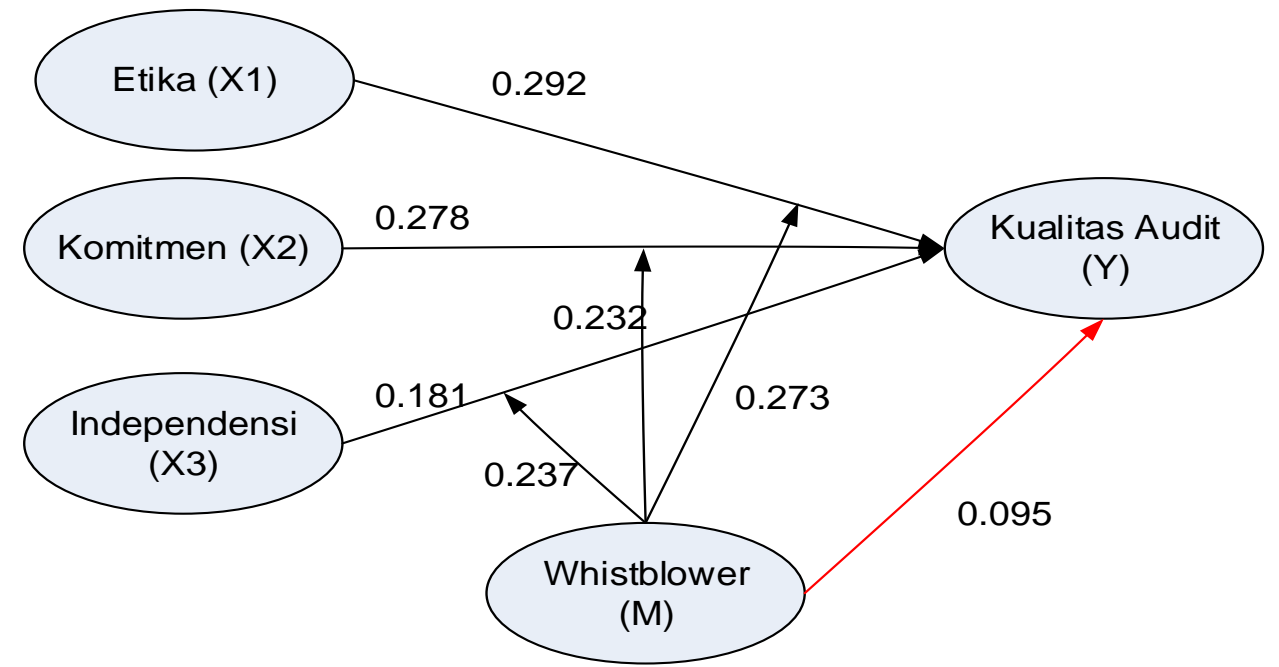

Figure:-PLS Structural Models

Source: Primary Data Processed, 2017 (Attachment 4)

\section{Discussions:-}

The following section will discuss the findings of the study. First, this study found that Ethics (X1) influences audit quality (Y). High ethics, which can be seen from the high concern for professional ethics (X1.1), ethical awareness (X1.2), and locus of control (X1.3) will have an impact on the high audit quality (Y) which is reflected in the aspects of job guidance field (Y.1), leadership involvement (Y.2), and audit work team (Y.3).

According to Cohen et al. (2001) that every individual action is first determined by his needs, whereas according to Ibrahim (2001) ethics is a personal discipline in relation to the environment which is more than what is only determined by the Act.

Quality audits according to the Indonesian Institute of Accountants if they meet auditing standards and quality control standards. Deis and Giroux (1992) explain that the ability to find material misstatements in a company's financial statements depends on the auditor's competence while the willingness to report the findings of the misstatement depends on its independence. Thus, the results of this study indicate that respondents' perceptions of concern for professional ethics, ethical awareness and locus of control have an impact on the high quality of audits reflected in aspects of the Guidelines for field work, involvement of leaders, and audit work teams in line with several previous studies.

Second, this study found that Commitment (X2) affects audit quality (Y). High commitment, which can be seen from the high Affective commitment (X2.1), Continuance commitment (X2.2), and Normative commitment (X2.3) will have an impact on the high audit quality (Y) which is reflected in the guideline aspects of field work (Y .1), Leadership involvement (Y.2), and audit work team (Y.3).

Organizational commitment according to Riggio (2000) is all the feelings and attitudes of employees towards everything related to the organization where they work, including their work. Buttery, Hurford, and Simpson (Audit in the Public Sector, 1993) mention some other personal qualities that an auditor must possess, such as intelligence, 
good behavior, high commitment, and good imagination ability to create creative attitudes and full of innovation. Siders et al. (2001), and Fernando et al (2005) from the results of their research, also gave the same conclusion that organizational commitment has a positive influence on performance. The results of this study are in line with previous research that accountants with strong professional commitment will lead to adherence to rules compared to accountants with low professional commitment.

Third, this study found that Independence (X3) influences audit quality (Y). High independence, which can be seen from the high personal auditor (X3.1), relationship with professional colleagues (X3.2), and the relationship with the audit (X3.3) will have an impact on the high audit quality (Y) which is reflected in the job guideline aspect field (Y.1), leadership involvement (Y.2), and audit work team (Y.3).

Independence means a mental attitude that is free from influence, not controlled by other parties, not dependent on others. Independence also means that there is honesty in the auditor in considering the facts and the existence of objective considerations that are not impartial in the auditor in formulating and expressing his opinion. Mulyadi (2002) defines the following: "Circumstances free from influence, not controlled by other parties, do not depend on other organizations. An independent public accountant must be a public accountant who is not affected and influenced by various forces that come from outside the self-accountant in considering the facts he encounters in the examination.

Fourth, this study found that Whistleblower (M) affects audit quality (Y). High Whistleblower, which can be seen from the high Accountability (M.1), Finding fraud (M.2), Participation of all parties (M.3), and the role of public interest (M.4) will have an impact on the high quality of audit (Y) reflected in the guideline aspects of field work (Y.1), leadership involvement (Y.2), and audit work team (Y.3).

Whistleblowing is the action of a worker who decides to report to the media, internal or external power about illegal and unethical matters that occur in the work environment. Whistleblowing is part of the control system, but for organizations that do not carry out their business activities unethically, Whistleblowing can be a threat. De George (1986) establishes three criteria for fair whistleblowing. First, an organization that can cause harm to its workers or to the broad public interest. Second, errors must be reported first to internal parties who have higher powers, and thirdly, if irregularities have been reported to internal authorities but have no results, and even irregularities continue, reporting of irregularities to external parties can be referred to as citizenship actions. The good one.

Fifth, the results found that the Whistleblower (M) variable moderated the influence of the Ethics variable (X1). Because the value of direct influence is not significant, but the interaction effect is significant on audit quality (Y) and the influence coefficient of interaction is positive, it can be said that the Whistleblower (M) variable is pure moderate and strengthens. This means that the higher the Whistleblower (M) value, the higher the influence of Ethics (X1) on audit quality (Y).

Whistleblowing is the action of a worker who decides to report to the media, internal or external power about illegal and unethical matters that occur in the work environment, a whistleblower is an employee (employee) or an employee in an organization that reports, witnesses, knows of a crime or the existence of practices that deviate and threaten the public interest in the organization and who decide to disclose these deviations to the public or authorized institutions (Wikipedia, Columbia Electronic Encyclopedia: 2005).

Whistleblower is useful as a tool to detect various problems that exist within the organization, such as discrimination, harassment, or other behavioral irregularities that are not in accordance with the ethical standards that apply in the organization. So, if implemented seriously, this whistleblower mechanism can also function as a means of control and supervision, which can help improve ethical behavior in the organization, which can also encourage changes in organizational culture in a better direction. This information giver can come from management, employees of an organization, or other parties who have interactions with organizational devices.

Sixth, found results that stated that the Whistleblower $(\mathrm{M})$ variable moderated the influence of the Commitment variable (X2). Because the value of direct influence is not significant, but the interaction effect is significant on audit quality (Y) and the influence coefficient of interaction is positive, it can be said that the Whistleblower (M) variable is pure moderate and strengthens. This means that the higher the Whistleblower $(\mathrm{M})$ value, the higher the influence of Commitment (X2) on Audit Quality (Y). 
Seventh, found results that stated that the Whistleblower $(\mathrm{M})$ variable moderated the influence of the Independence variable (X3). Because the value of direct influence is not significant, but the interaction effect is significant on audit quality (Y) and the influence coefficient of interaction is positive, it can be said that the Whistleblower (M) variable is pure moderate and strengthens. That is, the higher the Whistleblower (M) value, the higher the influence of Independence $(\mathrm{X} 3)$ on audit quality $(\mathrm{Y})$.

\section{Conclusions and Recommendations:-}

Based on the results and discussion in the previous chapter, the following conclusions are obtained:

1. Ethics influences audit quality. High ethics, which can be seen from the high concern for professional ethics, ethical awareness, and locus of control, will have an impact on the high quality of audit, which is reflected in the guideline aspects of field work, involvement of leaders, audit work team.

2. Commitment influences audit quality. High commitment, which can be seen from the high Affective commitment, Continuance commitment, and Normative commitment will have an impact on the high quality of audit, which is reflected in the aspects of Guidelines for field work, involvement of leaders, audit work team.

3. Independence influences audit quality, high independence, as evidenced by the high personal auditor, relationships with professional colleagues, the relationship with the audit will have an impact on high audit quality, which is reflected in the guideline aspects of field work, involvement of leaders, and audit work team.

4. Whistleblowers have no effect on audit quality, high Whistleblower, which can be seen from the high Accountability, Finding fraud, Participation of all parties, and Roles for the public interest will not have an impact on the quality of audit, which is reflected in the Guidelines for fieldwork, leadership involvement, and Audit work team.

5. Whistleblowing moderates the influence of ethics variables that are purely moderating and reinforcing. That is, the higher the Whistleblower value, the higher the influence of Ethics on audit quality.

6. Whistleblowing moderates the influence of Commitment variables that are pure moderation and strengthening. That is, the higher the Whistleblowing value, the higher the influence of Commitment to Audit Quality.

7. Whistleblowing moderates the influence of independence variables that are pure moderation and strengthens. That is, the higher the Whistleblowing value, the higher the influence of Commitment to Audit Quality

Based on the research conclusions, the following recommendations are recommended:

1. In this study, the variables studied are ethics, competence, independence, audit quality, are needed so that the internal auditor should examine starting from the process of budgeting, implementation, administration, to accountability.

2. Subsequent researchers should use qualitative research to study the behavior of government auditors as to why some regions receive the title of WTP but are accompanied by a large increase in corruption.

\section{References:-}

1. American Institute of Certified Public Accountants (AICPA). 2002. Statement on Auditing Standards. New York: AICPA.

2. Aranya, N., and K. Ferris, 1984. A Re-examination of Accountants Organizational Professional Conflict. The Accounting Review. 59 January (1-15).

3. Aranya, N., Lachman, R and Amernic, J. 1982. Accountants' Job Satisfaction: A Path Analysis. Accounting, Organizations and Society. Vol. 7, No. 3:201-215.

4. Aranya, N., Pollock, J and Amernic, J. 1981. An Examination of Professional Commitment in Public Accounting. Accounting, Organizations and Society. Vol. 6, No. 4:271-280.

5. Arrens, A.A and Loebbecke, J.K., 2008, Auditing: An Integrated Approach, Prentice Hall Inc., New Jersey.

6. Behn, B. K., J. V. Carcello., D. R. Hermanson. dan R. H. Hermanson. 1997. "The Determinants of Audit Client Satisfaction among Clients of Big 6 Firms. "Accounting Horizons,

7. Beasley, M.S., Carcello, J.V., and Hermanson, D.R. 2001. “Top 10 Audit Deficiencies." Journal of Accountancy. April. Pp. 63-66.

8. Boynton, W.C., Johnson, R.N., \& Kell, W.G., 2006, Modern Auditing, 8th Edition, USA Richard D. Irwin Inc.

9. Brown, C.D., Raghunandan, K., Audit Quality in Audits of Federal Programs by Non-Federal Auditors, Accounting Horizons, Vol. 9, No. 3, 1995.

10. Brown , 2007 Whistleblowing in the Australian Public Sector Enhancing the theory and practice of internal witness management in public sector organizations Published by ANU E Press The Australian National University Canberra ACT 0200, 
11. Buttery, Hurford, Simpson, 1993, Audit in the public sector.

12. Carcello, J. V., R. H. Hermanson, and N. T. McGrath. 1992. Audit Quality Attributes: The Perceptions of Audit Partners, Preparers, and Financial Statement Users. Auditing: A Journal of Practice and Theory

13. Carcello, J. V., D. R. Hermanson, and H. F. Huss. 1997. The effect of SAS no. 59: how treatment of the transition period influences results. Auditing: A Journal of Practice and Theory

14. Carcello, J., D. Hermanson, T. Neal, and R. Riley. 2002. Board characteristics and audit fees. Contemporary Accounting Research

15. Chiu, R.K. (2003), "Ethical judgment and whistle blowing intention: examining the moderating role of locus of control", Journal of Business Ethics, Vol.43 Nos 1/2, pp. 65-74.

16. Cohen, J.R., Pant, L.W. and Sharp, D.J. (2001), “An examination of differences in ethical decision-making between Canadian business students and accounting professionals", Journal of Business Ethics, Vol. 30 No. 4, pp. 319-36.

17. DeAngelo, LE. 1981. Auditor Size and Audit Quality, Journal of Accounting and Economics December 1981.

18. De George, R.T. 1986. Business Ethics, 2nd ed., Macmillan, Basingstoke.

19. Deis, D. R. dan Gary A. Giroux. 1992. "Determinants of Audit Quality in the Public-sector." The Accounting Review

20. Fernando, J., Mulki, J.P., dan Marshall, G.W. 2005. A Meta-Analysis of the Relationship between Organizational Commitment and Salesperson Job Performance. Journal of Business Research, (58) : $705-714$

21. Hair, J.F., Black, William C. Babin, Barry J. Anderson, Rolph E. Tatham, \& Ronald L. 2006. “Multivariate Data Analysis" 6th ed. Upper Saddle River, Prentice Hall International, Inc.

22. Indra Bastian. 2006 Akuntansi Sektor Publik: Suatu Pengantar. Penerbit Erlangga. Jakarta, bab 1 \& 2

23. James C. Lampe (1992). A Study of Whistleblowing among Auditors. Professional Ethics 1 (3/4):137-168. James C. Lampe (1992). Sebuah Studi Whistleblowing antara Auditor. Etika Profesional 1 (3/4) :137-168.

24. Jensen MC and JH Meckling, 1976, Theory of Firm : Managerial Behavior, Agency Cost and Ownership Structure, Journal of Financial Economics

25. Jeffrey, C. and Weatherholt, N. 1996. Ethical Development, Professional Commitment, and Rule Observance Attitudes: A Study Case of CPAs and Corporate Accountants. Behavioral Research in Accounting. Vol. 8; 8-31.

26. Lowensohn, S., L. E. Johnson., R. J. Elder dan S. P. Davies. 2007. "Auditor Specialization, Perceived Audit Quality, and Audit Fee in the Local Government Audit Market.” Journal Of Accounting and Public Policy,

27. Luthans, 1995 Organizational Behavior, seventh edition Mc Graw - Hill, Inc

28. Miceli, M. P. and Near, J. P. 1992. Blowing the Whistle: The Organizational and Legal Implications for Companies and Employees. Lexington, MA: Lexington Books.

29. Mock, T. J. dan M. Samet. 1982. A Multi Attribute Model for Audit Evaluation. In Proceedings of the VI University of Kansas Audit Symposium.

30. Mulyadi. 2002. Auditing. Edisi 6. Badan Penerbit Salemba Empat, Jakarta.

31. Nadler, Judy, and Miriam Schulman. "Campaign Ethics.” Santa Clara University 2011.

32. Near, J. P. and M. P. Miceli: 1996, 'Whistle-blowing: Myth and reality'. Journal of Management

33. Novianti Suzy, 2007. Skeptisme Profesional Auditor dalam Mendeteksi Kecurangan, The 1st Accounting Conference., FEUI.

34. Riggio R,. E, (2000), Introduction to industrial/Organizational Psychology. NJ: Prentice Hall

35. Rothschild, J. and T. D. Miethe: 1999, 'Whistle-blower disclosures and management retaliation'. Work and Occupations

36. Siders., 2001, Panduan Evaluasi Kinerja Karyawan, Jakarta: Prestasi Pust a k a Publisher

37. Smith, D and Hall, M. 2008. An Empirical Examination of a Three-Component Model of Professional Commitment Model of Professional Commitment among Public Accountant. Behavioral Research in Accounting. Vol. 20, No.1:75-92.

38. Soma Pillay and Nirmala Dorasamy 2011, Systemic factors moderating effective whistle blowing: An exploratory study into a public service organization Swinburne University of Technology, Hawthorn, Melbourne, Australia Afrika Journal Management Vol 5 (22).

39. Sugianto, 2011. Tesis tentang Hubungan Orientasi Etika, Komitmen Profesional, Sensitivitas Etis dengan Whistleblowing Perspektif Mahasiswa Akuntansi, Unhas

40. Sugiyono. 2002. Metode Penelitian Administrasi. Bandung: CV Alfabeta.

41. Syamsuddin, 2014, Whistleblower dan skeptisme profesional auditor pemerintah dalam menghasilkan kualitas audit (Survei Pada Badan Pemeriksa Keuangan Propinsi Sulawesi Selatan, Sulawesi Tengah dan Sulawesi Barat). Disertasi. Program Pascasarjana Universitas Hasanuddin. 
42. Suraida, 2003, Pengaruh Etika, Kompetensi, Pengalaman, Resiko Audit terhadap Skeptisisme Profesional Auditor dan Ketepatan Pemberian Opini Akuntan Publik. Disertasi. Program Pascasarjana Universitas Padjajaran Bandung.

43. Vanasco, Rocco R. Clifford R. Skousen and Curtis C. Verschoor, 1995, reporting on the entity's control structure, Managerial Auditing Journal, Vol 10.

44. Vardi, Y and Wiener, Y. 1996. Misbehavior in Organizations: A Motivational Framework. Organization Science. V.O1. 7, No. 2.

45. Varelius, J. 2009. Is Whistle-Blowing Compatible with Employee Loyalty. Journal of Business Ethics. 85:263275.

46. Vinten. G. 2000. Whistleblowing towards Disaster Prevention and Management. Disaster Prevention and Management. Vol. 9 No. 1:18-28.

47. Vinten, G. (Ed.) (1994), Whistleblowing - Subversion or Corporate Citizenship?,

48. Yuyun, 2007 Pengaruh Komitmen Profesional, Antisipasi Sosial, Skeptisme Profesional dan Penalaran Moral Mahasiswa Akuntansi Terhadap Whistleblowing

\section{Others}

49. BPKP. 1996. Standar Audit Aparat Pengawasan Fungsional Pemerintah (SA-APFP).

50. Kementrian Dalam Negeri dan Otonomi Daerah Republik Indonesia, 2001, Keputusan Menteri Dalam Negeri dan Otonomi Daerah Nomor: 17 Tahun 2001 Tanggal 12 Juli 2001 Tentang Pelimpahan Pengawasan Fungsional Penyelenggaraan Pemerintahan Daerah Kepada Gubernur.

51. Kementrian Pendayagunaan Aparatur Negara Republik Indonesia, 2005, Keputusan menteri Pendayagunaan Aparatur Negara Nomor: KEP/49/M.PAN/4/2005 Tentang Kebijakan Pengawasan Nasional Aparat Pengawasan Intern Pemerintah Tahun 2005 dan Program Kerja Pengawasan tahunan Penyelenggaraan Pemerintah Pusat Tahun 2005.

52. Komite Nasional Kebijakan Governance, 2008 tentang Sistem Pelaporan Pelnggaran (Whitleblowing)

53. Pedoman Whistleblowing dikeluarkan Komisi Nasional Kebijakan Governance 2008

54. Presiden Republik Indonesia, 2001, Keputusan Presiden Republik Indonesia No. 74 Tahun 2001 Tentang Tata Cara Pengawasan Penyelenggaraan Pemerintah Dearah.

55. Peraturan Badan Pemeriksa Keuangan Republik Indonesia Nomor 01 Tahun 2007.Standar Pemeriksaan Keuangan Negara. Jakarta

56. Peraturan Menteri Negara Pendayagunaan Aparatur Negara nomor PER/05/M.PAN/03/2008. Standar Audit Aparat Pengawasan InternPemerintah. Jakarta.

57. Kamus Besar Bahasa Indonesia edisi terbaru, 2012 